\title{
Students' Mathematical Problem Solving Abilities: The Impact of The Co-Op Co-Op Cooperative Learning Model and Missouri Mathematics Project
}

\author{
Rahma Faelasofi ${ }^{1,}{ }^{*}$, Risna Apriliani ${ }^{2}$, Walidatul Nafi' ah ${ }^{2}$ \\ ${ }^{1}$ Muhammadiyah University, Pringsewu, Indonesia \\ 2 Raden Intan State Islamic University of Lampung, Indonesia
}

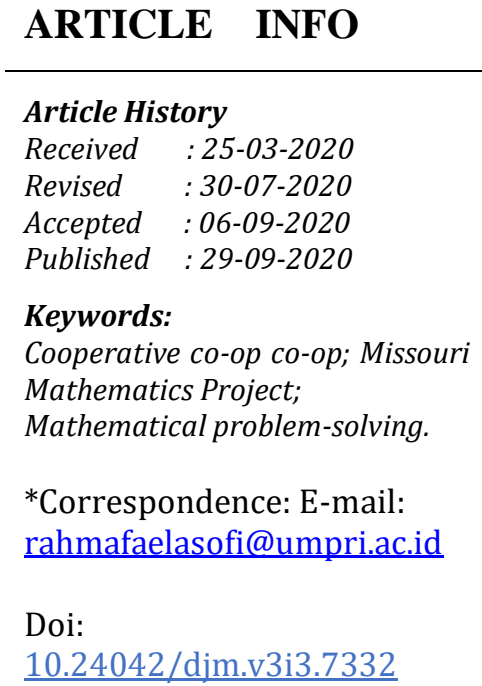

\section{ARTICLE INFO}

Keywords

10.24042/djm.v3i3.7332

\begin{abstract}
The development of the industrial revolution must be balanced by the increase of quality soft skills, one of which is problem-solving ability. This study was aimed to determine which learning models that have more influence on students' mathematical problem-solving abilities. Cooperative learning model Co-Op Co-Op with students who applied the Missouri Mathematics Project learning model. This research employed the quasi-experimental design. The sample was selected using cluster random sampling. The data collection instrument used was a problem-solving ability test in the form of an essay test. Based on the results of calculations using the t-test, it was concluded that the Co-Op Co-Op Cooperative learning model had more influence on students' mathematical problem-solving abilities compared to the Missouri Mathematics Project.
\end{abstract}

\section{INTRODUCTION}

Mathematics is a field of study aimed at solving problems. This opinion is in line with the standard content of the 2006 Curriculum that the problem-solving approach is the focus of mathematics learning that includes various types of problems (Amir, 2015). This opinion is also supported by the Ministry of National Education ( Rivai and Surya 2017) that one of the goals of learning mathematics in schools is to develop problem-solving abilities. Problem-solving ability is a soft skill needed in the process of solving problems to achieve the expected goals. The ability to solve mathematical problems has been widely researched, such as the ability to solve problems with the Osborn, M-apos, and exploration models (Lestari, 2015; Nurafifah et al., 2016; Sariningsih \& Purwaningsih, 2017) The cognitive style and motivation also have a positive influence in improving students' mathematical problem-solving abilities (Aspriyani, 2017; ulya, 2015). Based on several previous studies, the researchers were interested in conducting 
further research on problem-solving abilities through two different treatment comparisons.

Problem-solving abilities can be trained through appropriate methods. Students should find solutions through alternative ideas in solving problems related to mathematics (Faelasofi, 2017). Some models that are considered relevant to mathematical problem-solving abilities are the Co-Op Co-Op Cooperative learning model and the Missouri Mathematics Project (MMP). The Co-Op Co-Op Cooperative learning model is a group investigation that demands students' active role in working together to obtain an expected concept (Yanti, 2019). Several previous studies using the Co-Op Co-Op Cooperative model stated that this model is considered to be better in improving mathematical communication skills (nadia sari \& Susanti, 2019) and improving learning outcomes, and increasing student activeness and creativity (Di, 2016; Istiglal, 2018). The use of the CoOp Co-Op Cooperative learning model also plays a role in influencing mathematical problem-solving abilities in advanced calculus material (Qurohman, 2017). The mathematical problem-solving abilities can also be improved through the Co-Op Co-Op Cooperative model when viewed from the learning style (Henri et al., 2018; Naldi \& Susanti, 2018) and the Bredic-Observe Explain approach (Maryanti, 2018). Apart from the mentioned studies, some studies state that the model does not affect critical thinking skills (Emil Maulana, 2018).

The Missouri Mathematics Project (MMP) learning model is a learning model that provides students the opportunity to work together in small groups and apply their respective understandings through worksheets (Rivai \& Surya, 2017). This model also demands the role of the teacher as a facilitator and a reference in implementing a learning activity. Many previous studies applied to the Missouri Mathematics Project (MMP). The MMP model is considered good for improving mathematical reasoning skills (Rivai \& Surya, 2017) and solving mathematical problems (Rahmiati \& Fahrurrozi, 2016; Sadat, 2016; Setyawan Putra \& Fitriyani, 2017). Also, this model assisted by origami and relief media has a significant effect on student learning outcomes (Bagja sulfemi \& Desmiati, 2006; Rahayu, 2018).

Based on the description, the two models influence problem-solving abilities. Therefore, the researchers were interested in conducting a study on students' mathematical problem-solving abilities through a comparison of the CoOp Co-Op Cooperative learning model and the Missouri Mathematics Project (MMP) learning model. The novelty of this study compared to several previous studies lays in the use of two learning models. The researchers wanted to know which learning models provided more influence on students' mathematical problemsolving abilities.

\section{RESEARCH METHOD}

This study employed the quasiexperimental procedure with the quasiexperimental design. The sampling technique used was cluster random sampling. According to (Yusri et al., 2018), the data collection technique employed was a test instrument to test the problem-solving abilities in the form of a description test. The design of the study can be seen in Figure 1. 
Desimal, 3 (3), 2020 - 281

Rahma Faelasofi, Risna Apriliani, Walidatul Nafi'ah

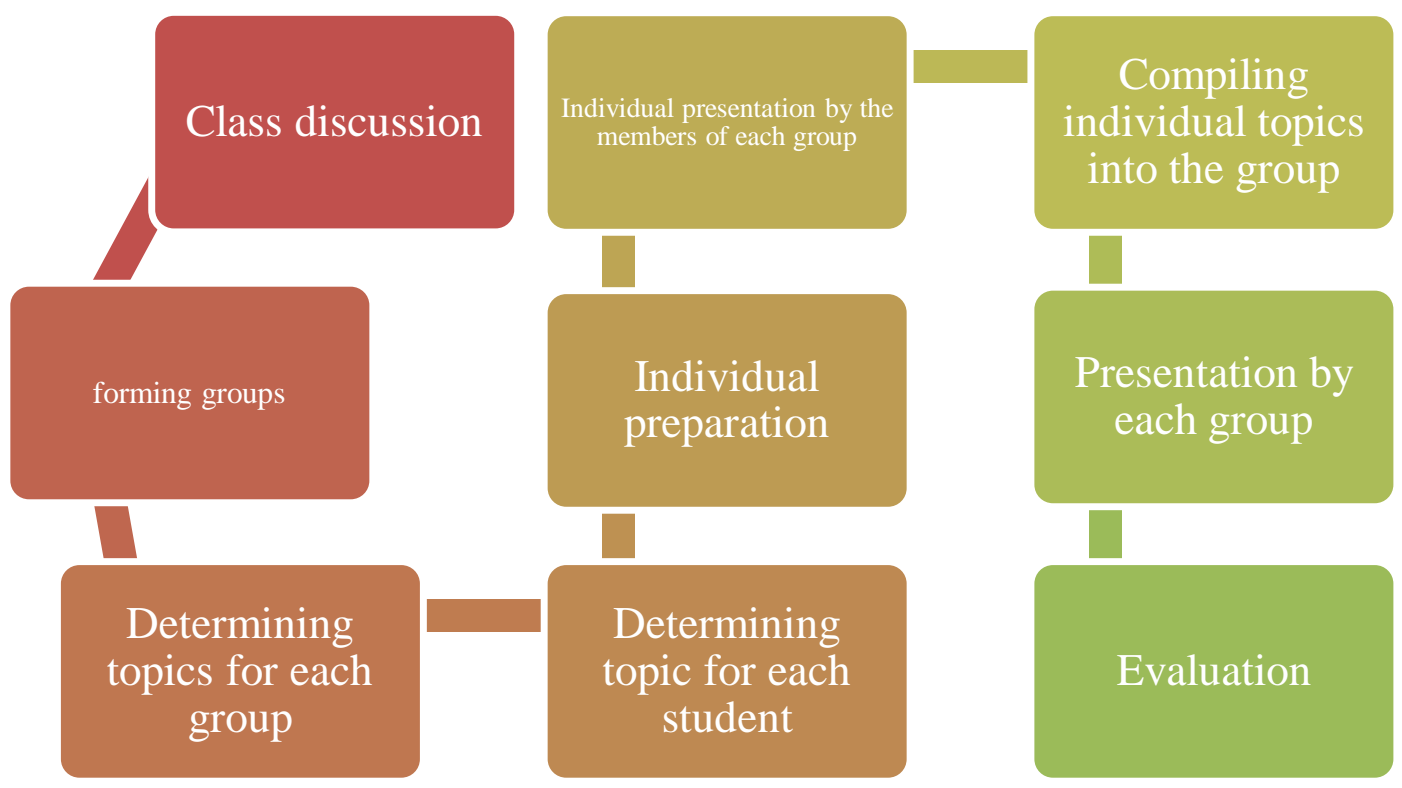

Figure 1. The Procedure of Co-Op Co-Op Cooperative Model

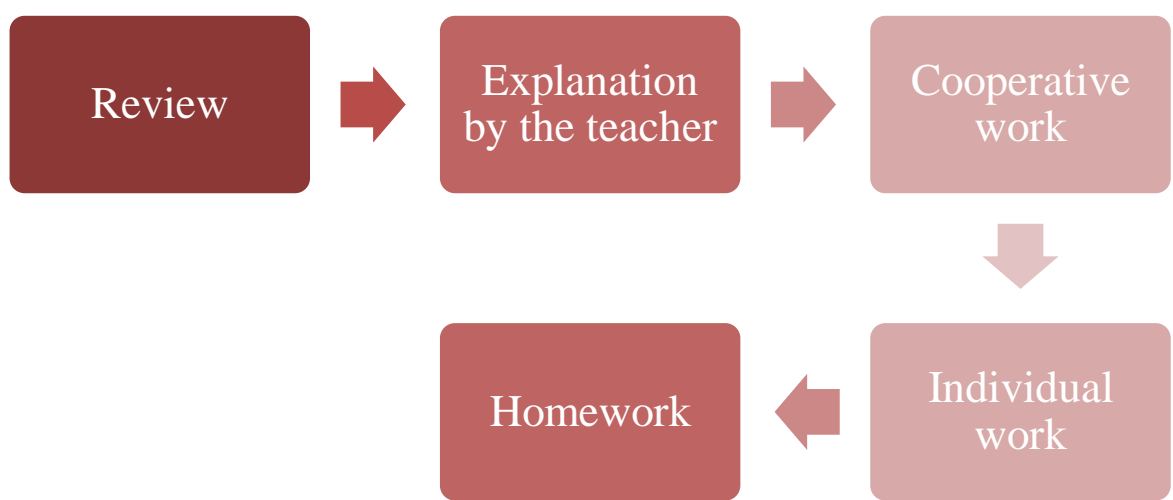

Figure 2. The Procedure of the MMP Model

Based on Figure 1, the first step of the Co-Op Co-Op Cooperative learning model is a class discussion where students express their opinions on a particular topic. Then the teacher forms groups of 4-5 students. At this stage, let each group decide what topics to discuss. Then, each member of the group determines their respective topics based on the group's predetermined topic. Each group member looks for references on the topics they have chosen. After the material has been deemed sufficient, each group member presents the material in front of small groups. Each group member put together the individual discussion results. Furthermore, each group presents the results of their group work and ends with an evaluation by all class elements (Istiglal, 2018).

The first step of the MMP model begins with a review of the previous material carried out by the teacher by asking questions to students to remind them about the material that has been previously presented. In the next stage, the teacher explains the material to be studied within half an hour. Then, students work in groups to complete group assignments given by the teacher. After that, each student does the assignment individually. The last stage is the provision of homework by the teacher so that students repeat the material they have learned at home (Rahayu, 2018). 
Desimal, 3 (3), 2020 - 282

Rahma Faelasofi, Risna Apriliani, Walidatul Nafi'ah

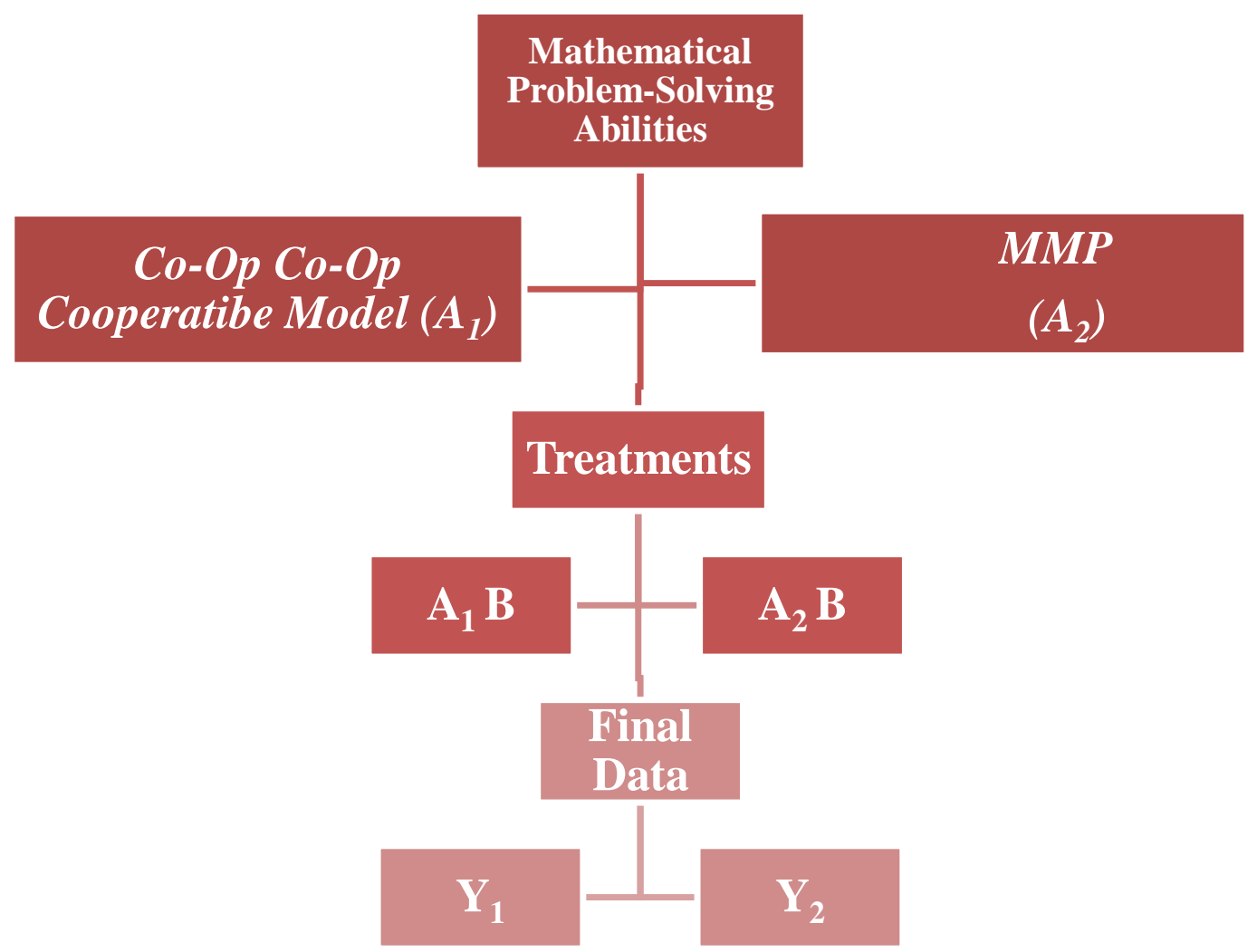

Figure 3. Research Design Scheme

Description:

A1: Learning Model

B: Mathematical problem-solving abilities

A1: Co-op Co-op Cooperative model

A2: MMP Learning Model

$\mathrm{A}_{1} \mathrm{~B}$ : Problem-solving abilities with Co-op Co-op Cooperative model

A2 B: Problem-solving abilities with the MMP Model

Y1 \& Y2: Final Results (Posttest)

The test administered in this study was a posttest of 10 description questions. The posttest had been constructed based on indicators of mathematical problem- solving abilities. The test was conducted to determine students' mathematical problem-solving abilities after being given the treatment of the Co-op Co-op Cooperative and MMP learning models. The hypothesis testing was done by using an independent sample t-test.

\section{RESULTS AND DISCUSSION}

Based on the results of the analysis of students' mathematical problem-solving abilities in the two sample classes, the data of the descriptive statistics test can be seen in Table 3.

Table 3. Descriptive Statistics of Mathematical Problem-Solving Abilities

\begin{tabular}{|c|c|c|c|c|c|c|c|c|}
\hline & Mean & Median & Mode & Max & Min & Variance & Sd & Range \\
\hline $\begin{array}{l}\text { Co-op Co-op } \\
\text { Cooperative }\end{array}$ & 75,767 & 80 & 88 & 90 & 35 & 171,978 & $\begin{array}{c}13,114 \\
0\end{array}$ & 55 \\
\hline $\begin{array}{l}\text { Missouri } \\
\text { Mathematics } \\
\text { Project }\end{array}$ & 71,075 & 70 & 68 & 88 & 45 & 93,917 & 9,6911 & 43 \\
\hline
\end{tabular}

Based on Table 3, it can be seen that the mean and median values of the Co-op Co-op Cooperative learning model were greater than the Missouri Mathematics
Project learning model. It indicated that the Co-op Co-op model significantly influences students' mathematical problem-solving abilities compared to the 
Desimal, 3 (3), 2020 - 283

Rahma Faelasofi, Risna Apriliani, Walidatul Nafi'ah

Missouri Mathematics Project (MMP) learning model.

Furthermore, the independent sample t-test was carried out to compare whether there was a difference in the average students' learning outcomes. The hypotheses of the study are:

$\mathrm{H}_{0}=$ There is a significant difference in the mathematical problem-solving abilities between Co-op Co-op Cooperative learning model and the MMP learning model.

$H_{1}=$ There is no significant difference in the mathematical problem-solving abilities between Co-op Co-op Cooperative learning model and the MMP learning model.

Table 4. The Results of t-Test

\begin{tabular}{lcccccc}
\hline & $\begin{array}{c}\text { Levene's Test for } \\
\text { Equality of } \\
\text { Variances }\end{array}$ & & \multicolumn{2}{c}{ t-test Equality of Means } \\
& F $\quad$ Sig. & T & $\begin{array}{c}\text { Sig. (2- } \\
\text { tailed) }\end{array}$ & $\begin{array}{c}\text { Mean } \\
\text { Difference }\end{array}$ & $\begin{array}{c}\text { Std. Error } \\
\text { Difference }\end{array}$ \\
$\begin{array}{l}\text { Mathematical Problem } \\
\begin{array}{l}\text { Solving Ability Co-op Co- } \\
\text { op Cooperative Learning }\end{array}\end{array}$ & $3,520 \quad, 065$ & 1,722 &, 090 & 4,6917 & 2,7241 \\
$\begin{array}{l}\text { Model and MMP Learning } \\
\text { Model }\end{array}$ & & & 1,650 &, 105 & 4,6917 & 2,8426 \\
\hline
\end{tabular}

Testing criteria:

$$
\begin{aligned}
& H_{0}: \mu_{1} \leq \mu_{2} \\
& H_{1}: \mu_{1}>\mu_{2}
\end{aligned}
$$

If $t_{\text {observed }} \leq t_{\text {critical }}$, then $H_{0}$ is accepted.

In Table 2 , the t-value was 1.722 .

Based on the testing criteria, it was found that $t_{\text {observed }} \leq t_{\text {critical }}=1.722 \leq$ 1.99547, then $\mathrm{H}_{0}$ was accepted. It indicated that the Co-op Co-op Cooperative learning model significantly influenced students' mathematical problem-solving abilities compared to the Missouri Mathematics Project (MMP) model. This means that the application of the Co-op Co-op Cooperative learning model provided a more significant impact on students' mathematical problemsolving abilities.

The Co-op Co-op cooperative learning model was more influential than the Missouri Mathematics Project (MMP) learning model. The results of this study are in line with previous research which states that the Co-op Co-op Cooperative learning model affects critical thinking skills, problem-solving abilities, concept understanding, calculus problem-solving, and students' learning outcomes (Henri et al., 2018; Naldi \& Susanti, 2018; Pristanty \& Krisdiana, 2018; Qurohman, 2017). Other research also states that the Co-op Co-op Cooperative learning model affects the activeness and creativity, mathematical communication skills, and student learning outcomes (Anggit setiari, rahmi susanti, 2016; Irawati et al., 2019; Istiglal, 2018; nadia sari \& Susanti, 2019).

Based on the steps in Figure 1, the initial stage of the Co-op Co-op Cooperative learning model begins with a class discussion where all class elements submit their respective arguments about a particular topic. This is in line with the first step of the MMP model where all class elements discuss topics that have been previously discussed. The individual preparation steps in the Co-op Co-op Cooperative learning model are the same as the explanatory steps by the teacher in the MMP model. However, in the Co-op Coop cooperative learning model, students play a more active role in finding material while in the MMP model, the teacher is dominant in providing material. The group preparation and group presentation steps of the Co-op Co-op Cooperative learning model are in line with the third step of the MMP model where each group works together to discuss a particular topic. The 
difference between the two models is that in the Co-op Co-op Cooperative learning model, students work together to find solutions to problems and present them while in the MMP model, students only work together in working on the questions given by the teacher. The final step of the two models is an evaluation where students and teachers are actively involved.

Based on the description, the teacher acts as a facilitator in the Co-op Co-op Cooperative learning model while in the Missouri Mathematics Project (MMP) model, the teacher still plays a dominant role because $50 \%$ of the time is used by the teacher. This causes the Co-op Co-op Cooperative learning model to influence students' problem-solving abilities because students are required to fully participate in learning. This opinion is supported by previous research which states that the Co-op Co-op Cooperative learning model can improve students' mathematical problem-solving abilities (Qurohman, 2017). Besides, the selection and application of appropriate learning models will have a big role in improving students' abilities. A good teaching model is a model that can make students do various kinds of activities to train their abilities so that their understanding of mathematical concepts and mathematical problem-solving abilities can be better (Ardiansyah \& Faelasofi, 2019).

\section{CONCLUSION AND SUGGESTION}

Based on the theoretical descriptions and the results of the calculation, it can be concluded that there was an influence on mathematical problem-solving abilities. The Co-op Coop Cooperative learning model had a more significant impact than the Missouri Mathematics Project (MMP) learning model on mathematical problem-solving abilities. Therefore, the Co-op Co-op Cooperative learning model can be used as an alternative to be applied in learning activities.

It is suggested for further researchers to conduct research using similar or different variables or learning models so that supporting aspects can be added to improve the quality of education.

\section{REFERENCES}

Amir, M. F. (2015). Pengaruh pembelajaran konstektual terhadap kemampuan pemecahan masalah matematika siswa sekolah dasar. Prosiding Seminar Nasional Pendidikan, 2011, 34-42. https://doi.org/10.3917/rsi.100.010 7

Anggit setiari, rahmi susanti, S. (2016). Pengaruh penerapan model pembelajaran co-op co-op terhadap hasil belajar peserta didik pada materi sistem ekskresi kelas XI di SMA Negeri 1 Buay Madang. 22, 404-414.

Ardiansyah, \& Faelasofi, R. (2019). Peningkatan hasil belajar siswa pada pembelajaran matematika. Jurnal EDuMath, 5(1), 31-37.

Aspriyani, R. (2017). Pengaruh motivasi berprestasi siswa terhadap kemampuan pemecahan masalah matematis. Jurnal Penelitian Dan Pembelajaran Matematika, 10(1). https://doi.org/10.30870/jppm.v10i 1.1194

Bagja sulfemi, W., \& Desmiati, Z. (2006). Model pembelajaran missouri mathematics project berbantu media relief experience dalam meningkatkan hasil belajar siswa. PENDAS MAHAKAM: Jurnal Pendidikan Dasar, 3(2003), 2006.

Di, J. (2016). Meningkatkan keaktifan dan kreativitas siswa dengan metode coop co-op dan strategi peninjauan kembali. Attarbiyah, 26, 205. https://doi.org/10.18326/tarbiyah.v 26i0.205-232

Faelasofi, R. (2017). Identifikasi kemampuan berpikir kreatif matematika pokok bahasan peluang. JURNAL E-DuMath, 3(2), 155-163. https://doi.org/10.26638/je.460.20 64

Henri, H., Syamsurizal, S., \& Syaiful, S. (2018). Pengaruh model co-op co-op 
Desimal, 3 (3), 2020 - 285

Rahma Faelasofi, Risna Apriliani, Walidatul Nafi'ah

mandiri terhadap kemampuan pemecahan masalah ditinjau dari gaya belajar siswa. AKSIOMA: Jurnal Program Studi Pendidikan Matematika, $\quad 7(3), \quad 482$. https://doi.org/10.24127/ajpm.v7i3 .1583

Irawati, I., Hasmunir, H., \& wahab abdi, A. (2019). Penerapan model pembelajaran kooperatif tipe co-op co- op dengan media video untuk meningkatkan hasil belajar siswa pada pelajaran IPS terpadu kelas VII MTsN Angkup Aceh Tengah. Concept and Communication, null(23), 301316.

https://doi.org/10.15797/concom.2 019..23.009

Istiglal, M. (2018). Pola penerapan metode co-op co-op dan strategi peninjauan kembali dalam pembelajaran matematika untuk meningkatkan keaktifan dan kreativitas siswa. Jurnal Matematika Dan Pembelajaran, 6(1), 70-90.

Lestari, K. E. K. A. (2015). Penerapan model pembelajaran M-APOS untuk meningkatkan kemampuan pemecahan masalah matematis siswa SMP. Jurnal Pendidikan UNISKA, 3, 45-52.

Maryanti, S. (2018). Model pembelajaran kooperatif co-op co-op dengan pendekatan predict-observe-explain untuk meningkatkan kemampuan pemecahan masalah matematis. Desimal: Jurnal Matematika, 1(3), 293-302.

https://doi.org/10.24042/djm.v1i3. 2680

nadia sari, S., \& Susanti, A. (2019). Eksperimentasi model pembelajaran co-op-co-op terhadap kemampuan komunikasi matematis ditinjau dari minat belajar siswa. Jurnal Pendidikan Matematika, 53(9), 16891699.

https://doi.org/10.1017/CB097811 07415324.004
Naldi, F., \& Susanti, A. (2018). Pengaruh model pembelajaran co-op co-op terhadap pemahaman konsep ditinjau dari gaya belajar visual, Audio, Kinestetik Siswa Kelas VIII SMPN 43 Merangin. Edumatica: Jurnal Pendidikan Matematika, 8(01), 23-35.

https://doi.org/10.22437/EDUMATI CA.V8I01.4115

Nurafifah, L., Nurlaelah, E., \& Usdiyana, D. (2016). Model pembelajaran osborn untuk meningkatkan kemampuan pemecahan masalah matematis siswa. MA T H L I N E: Jurnal Matematika Dan Pendidikan Matematika, 1(2), 93-102. https://doi.org/10.31943/mathline. v1i2.21

Pristanty, A. W., \& Krisdiana, I. (2018). Efektivitas model pembelajaran kooperatif tipe co-op dan realistic mathematic education ( RME ) terhadap prestasi belajar matematika siswa kelas VIII ditinjau dari gaya belajar. Prosiding Silogisme, 81, 208214.

Qurohman, M. T. (2017). Meningkatkan kemampuan pemecahan masalah kalkulus lanjut melalui pembelajaran kooperatif tipe co-op co-op. Cakrawala: Jurnal Pendidikan, 11(1), 32.

https://doi.org/10.24905/cakrawala .v11i1.664

Rahayu, P. (2018). Penerapan model pembelajaran missouri mathematics project dengan media kertas origami untuk meningkatkan hasil. Prosiding SNasPPM, 3(1), 148-152.

Rahmiati, R., \& Fahrurrozi, F. (2016). Pengaruh pembelajaran missouri mathematics project (MMP) terhadap kemampuan pemecahan masalah matematika. Jurnal Pendidikan Matematika, 10(2), 1-12. https://doi.org/10.22342/jpm.10.2. 3634.75-86

Rivai, M. A., \& Surya, E. (2017). Analisis 
Desimal, 3 (3), 2020 - 286

Rahma Faelasofi, Risna Apriliani, Walidatul Nafi'ah

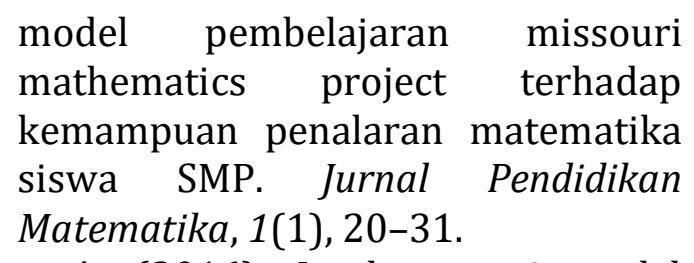

Sadat, A. (2016). Implementasi model pembelajaran missouri mathematics projectdalam upaya meningkatkan kemampuan pemecahan masalah matematis dan self- confidence siswa madrasah tsanawiyah. Didaktik: Jurnal Ilmiah PGSD STKIP Subang, 2(1), 1-11.

Sariningsih, R., \& Purwaningsih, R. (2017). Pembelajaran problem based learning untuk meningkatkan kemampuan pemecahan masalah matematis dan self efficacy mahasiswa calon guru. Dunia Keperawatan, 1(2), 34-42.

Setyawan Putra, S., \& Fitriyani, H. (2017). Pembelajaran matematika dengan model missouri mathematics projectuntuk meningkatkan kemampuan pemecahan masalah matematika siswa SMP. Seminar Nasional Pendidikan, Sains Dan Teknologi, 1(1), 312-319.

ulya, himmatul. (2015). Hubungan gaya kognitif dengan kemampuan pemecahan masalah matematika siswa. Jurnal Konseling GUSJIGANG, $1(2)$.

Yanti, L. (2019). Pengaruh model pembelajaran kooperatif co-op co-op terhadap keterampilan menulis teks eksposisi pada siswa kelas VIII B SMP Negeri 1 Singkawang. Cakrawala Linguista, $\quad 1(2), \quad 98$. https://doi.org/10.26737/cling.v1i2. 879

Yusri, A. Y., Andi, S., \& Pangkep, M. (2018). Pengaruh model pembelajaran problem based learning terhadap kemampuan pemecahan masalah matematika. Mosharafa: Jurnal Pendidikan Matematika, 7, 51-62. 